\title{
Law in Roman Society: an interview with Paul J. Du Plessis
}

\author{
O Direito na sociedade romana: uma entrevista com
}

Paul J. Du Plessis

\section{Paul J. Du Plessis*}

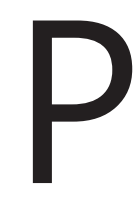

aul J. Du Plessis é professor de Direito Romano na University of Edinburgh, no Reino Unido. Formado pela Erasmus University, Rotterdam, Paul Du Plessis atua na área de História do Direito e Direito Romano. Paul Du Plessis é diretor do Centre for Legal History da University of Edinburgh, no qual realiza encontros periódicos por meio do Edinburgh Roman Law Group. ${ }^{1}$ É também autor de vários livros importantes para o estudo do Direito e da justiça no contexto da sociedade romana. No conjunto de suas publicações, Du Plessis dedica especial atenção à produção de manuais didáticos sobre o direito na sociedade romana, como, por exemplo, The Oxford Handbook of Roman Law and Society, que organizou com Clifford Ando e Kaius Tuori; e Borkowski's Textbook on Roman Law. Não obstante, também possui uma vasta produção especializada sob a forma de artigos, capítulos de livros e livros autorais. ${ }^{2} \mathrm{O}$ foco de suas reflexões é sobre a relação entre Direito e sociedade à luz do contexto histórico. Além disso, como podemos observar pela significativa quantidade de obras editadas, Du Plessis se insere numa rede de pesquisadores que, hoje, tem produzido importantes e História do Direito Romano significativas reflexões numa área que, no Brasil, podemos definir como.

\section{1. Érica Cristhyane Morais da Silva: What sparked your interest in studying Roman Law?}

Paul J. Du Plessis: I have always been passionate about the law ever since I was young. It was something mysterious and I wanted to know more about it. When I started studying history in secondary school, I realised that law had a rich and complex history. I was studying Latin at the same time. When I came to university, it seemed natural to study law,

\footnotetext{
"Entrevista concedida a Érica Cristhyane Morais da Silva em 14 de novembro de 2019.

${ }^{1}$ A homepage do Centre for Legal History pode ser visitada no seguinte endereço: <https://www.law.ed.ac.uk/research/ research-centres-and-networks/centre-for-legal-history>.

2 Vide algumas das obras de Paul J. Du Plessis: The slave in the window (2010); Studying Roman law (2012a); Theory and Practice in the Roman law of Contracts (2012b); e Urban landlords and tenants (2016). No momento, sua mais recente obra, Provincial Law' in Britannia, se encontra no prelo.
} 
but I did not want to give up studying history, so I did both. I had always been passionate about the Romans, so studying their law seemed a natural progression. When I realised, after having studied Roman law, how important it was for the development of modern law, I was hooked.

2. We know that your main field of studies is "Legal History". How would you define it?

R: To me, legal history as a field of study is more than merely an account of the past events that have shaped contemporary law. While studies of this kind have a place, they can be dangerous as well, if used for ideological purposes. To me, legal history is about conversations across centuries [or millennia] about shared themes and ideas that have shaped our law.

3. According to you, in how many ways the study of Ancient Law can improve our knowledge about the Roman society?

R: There are, at least, three reasons to study and teach Roman law. First, Roman law played a fundamental role in the development of contemporary private law, whether in civil-law or mixed legal systems. It also influenced and continues to influence the common law. In second place, Roman law is unparalleled when it comes to teaching students how to solve complex legal problems. The cased-based discussions of the Republican and classical jurists are without comparison and can be used to great effect, even in legal systems that thrive on the "casebook method" such as in the USA. The third reason is because it gives us an opportunity to analyse legal change in the past. By looking at legal developments in the past, we can ask larger questions about law and its relationship to other forces of change within society. It is this last reason that has fascinated me. I am thoroughly convinced, having read much of contemporary sociology of law, that the relationship between law and society is much more abstract and convoluted than people realise. Law is not a mirror of society. It has some links to society, but it does not "reflect" all of our hopes and aspirations.

4. In recent years we have noticed, in Brazil, the appearance of several publications on Roman Law, as such a Portuguese translation of the Justinian's Digest. This phenomenon seems connected with an international movement, for Roman Law has been a subject which has attracted the interest of lots of academics. How could you explain that? 
R: There is definitely a renewed interest in Roman law in the English-speaking world. It is difficult to pinpoint the reasons for this. I would say that, in my view, a much larger group of academics are interested in Roman law than before and these academics are not necessarily just in one discipline as was traditionally the case. Since most of this type of work is interdisciplinary and is done in English-speaking countries, it stands to reason that more exciting work will be produced by these scholars.

5. Undoubtedly the Roman Codes are the most self-evident source to research on Roman Law in Late Antiquity. But there will be other primary sources that would allow us to write about the Roman legal system?

R: Although the "traditional" legal sources are useful, they present only one side of the picture. If, as I do, one believes that the Roman legal system was embedded in the world of the Romans, it stands to reason that the less traditional sources could also be looked at once more to see if we have missed anything. Papyri and other epigraphic discoveries are particularly useful in this regard as they reveal "legal practice".

6. A lot of works on Roman Law has been published throughout the last decade, as we have mentioned. Therefore, we have today a great deal of knowledge about "Family Law", "Criminal Law", "Private Law", and "Maritime Law". Which subjects on Roman Law has not been yet studied by classical scholars?

R: There is definitely much work to be done on legal pluralism, especially in light of the recent work on the Constitutio Antoniniana and its effect on local law.

7. What major difference is there between the legal system of the Principate in comparison to the Late Antiquity one?

R: I think there are great parallels. It is no accident of history that Roman law proved so successful in the creation of modern law. With that said, one needs to be careful not to transpose modern ideas onto ancient law. Or, at least, if one does, to be honest about it. I do not think, for example, that Roman law was a "system" in the modern, scientific sense. This was a reinterpretation of the early-modern period. Yes, Roman law was "systematic", but in its own way and not in an early-modern way. I also think that Roman law - especially the overly developed private law - is a product of an pre-industrial state without the enforcement mechanisms inherent in a modern state. 
8. Although jurists have an approach on Law distinguishable from the approach adopted by the historians and sociologists, they have been incorporating in their works some of the social theories, for example the concept of "legal culture". In your opinion, would this concept be useful to cast new light on the Roman Law studies?

R: Yes, to me legal culture is a fundamentally important concept. Rules of law do not merely transplant easily because of their content. They also transplant more easily if the culture is broadly conducive to their borrowing.

9. Could you tell us something about your next book?

R: I have begun to work on a book about Roman property law. My intention is to look at the economic aspects of Roman property law with a view to determining to what extent its growth was underpinned by economic considerations.

10. Which piece of advice would you give to the students interested in Roman Law research?

R: There is no "one" way to look at Roman law. People investigate these texts in many different contexts and for many different purposes. 